\title{
Pengaruh Penerapan Strategi Metakognitif terhadap Kemampuan Komunikasi Matematis Berdasarkan Kemandirian Belajar Siswa Sekolah Menengah Pertama Pekanbaru
}

\author{
Septiani Putri Lestari, Ramon Muhandaz*, dan Risnawati \\ Jurusan Pendidikan Matematika, Universitas Islam Negeri Sultan Syarif Kasim Riau \\ e-mail: *ramon.muhan@uin-suska.ac.id
}

\begin{abstract}
ABSTRAK. Penelitian ini dilatarbelakangi pentingnya kemampuan komunikasi matematis dan pencapaiannya yang masih rendah. Tujuan penelitian ini adalah untuk mengetahui pengaruh penerapan strategi metakognitif terhadap kemampuan komunikasi matematis berdasarkan kemandirian belajar siswa Sekolah Menengah Pertama Pekanbaru. Jenis penelitian ini adalah quasi experimental dengan desain nonequivalent postest-only control group design. Populasi dalam penelitian ini adalah seluruh siswa kelas VIII SMPN 13 Pekanbaru. Sampel penelitian adalah siswa kelas VIII-3 sebagai kelas eksperimen dan siswa kelas VIII-8 sebagai kelas kontrol. Instrumen penelitian yang digunakan adalah tes kemampuan komunikasi matematis, angket kemandirian belajar dan lembar observasi. Berdasarkan hasil uji-t menunjukan terdapat perbedaan kemampuan komunikasi matematis antara siswa yang mengikuti pembelajaran dengan strategi metakognitif dengan siswa yang mengikuti tanpa strategi metakognitif. Berdasarkan hasil uji anova dua arah dapat disimpulkan terdapatperbedaan kemampuan komunikasi matematis antara siswa yang memiliki kemandirian belajar tinggi, sedang, dan rendah serta tidak terdapat interaksi antara strategi metakognitif dengan kemandirian belajar dalam mempengaruhi kemampuan komunikasi matematis siswa.
\end{abstract}

Kata kunci: Kemampuan Komunikasi Matematis, Kemandirian Belajar Siswa, Strategi Metakognitif.

\section{PENDAHULUAN}

Komunikasi matematis merupakan salah satu kompetensi yang harus dikembangkan pada setiap topik pembelajaran matematika. Hal ini karena salah satu standar proses pembelajaran matematika yang dirumuskan oleh NCTM (Noviarni, 2014) adalah kemampuan komunikasi. Permendikbud Nomor 21 Tahun 2016 (Permendikbud, 2016) juga menetapkan kemampuan komunikasi matematis sebagai salah satu kompetensi yang harus dicapai dalam pembelajaran matematika di sekolah yakni memiliki kemampuan mengkomunikasikan gagasan matematika dengan jelas

Ada alasan penting mengapa komunikasi matematis perlu ditumbuhkembangkan di kalangan siswa. Pertama matematika pada dasarnya adalah sebuah bahasa bagi matematika itu sendiri. Kedua, belajar dan mengajar matematika merupakan aktivitas sosial yang melibatkan paling sedikit dua pihak, yaitu guru dan murid (Ansari, 2015). Dengan demikian matematika tidak hanya sebagai alat untuk berpikir dalam memahami sebuah konsep, memecahkan permasalahan dan menarik kesimpulan, tetapi juga sebuah alat untuk mengomunikasikan ide pemikiran dengan jelas dan tepat. Artinya, bahwa kemampuan komunikasi matematis sangatlah penting.

Dalam pembelajaran matematika, kemampuan komunikasi matematis adalah kemampuan menyampaikan gagasan atau ide matematis baik secara lisan maupun tulisan serta kemampuan memahami dan menerima gagasan/ide matematis orang lain secara cermat, analitis kritis dan evaluative untuk mempertajam pemahaman (Hendriana, Rohaeti \& Sumarmo, 2017). Kemampuan komunikasi matematis lisan seperti reading, listening, discussing, explaining dan sharing. 
Kemampuan komunikasi matematis tulisan seperti mengungkapkan ide matematika melalui grafik, gambar,tabel, persamaan aljabar ataupun dengan bahasa sehari-hari (Ansari, 2015).

Namun kenyataannya, kemampuan komunikasi matematis masih rendah. Hasil penelitian oleh Andronikus et al (2016) menyatakan bahwa siswa belum dapat menyatakan dan menyelesaikan soal yang berbentuk cerita ke dalam bentuk model matematika yang berbentuk persamaan. Selanjutnya, hasil penelitian oleh Tupa (2015) menunjukkan bahwa siswa masih sukar membahasakan soal ke dalam simbol matematika khususnya dalam penyelesaian soal cerita.

Dari masalah tersebut dapat diketahui bahwa pentingnya suatu strategi pembelajaran untuk mengembangkan kemampuan komunikasi matematis. Hal ini dipertegas oleh Syah (2010) bahwa salah satu faktor yang mempengaruhi hasil belajar siswa adalah strategi dan metode yang digunakan siswa untuk melakukan kegiatan pembelajaran materi-materi pelajaran. Strategi pembelajaran yang mungkin cocok untuk memfasilitasi kemampuan komunikasi matematis adalah strategi yang proses pembelajarannya lebih banyak melibatkan siswa secara aktif. Salah satunya yaitu dengan menggunakan strategi metakognitif.

Menurut Kellough (Yamin, 2003) strategi metakognitif mengkondisikan pembelajar yang aktif merencanakan, memonitor, mengevaluasi kemajuan berpikir dan belajar. Ciri utama dalam pembelajaran metakognitif menurut Zakaria, Nordin \& Ahmad (2007) adalah pertanyaanpertanyaan metakognitif yang di dalamnya terdapat tiga jenis pertanyaan yaitu pertanyaan perencaaan, pemantauan dan evaluasi. NCTM juga menyatakan (Ansari, 2015) bahwa salah satu cara untuk mengembangkan kemampuan komunikasi matematis siswa yaitu menjelaskan dan mengajukan serta memperluas pertanyaan terhadap matematika yang telah dipelajari. Howard (2004) menegaskan bahwa metakognitif memegang peranan penting pada banyak tipe aktivitas kognitif termasuk pemahaman, komunikasi, perhatian (attention), ingatan (memory), dan pemecahan masalah. Oleh karena itu, pembelajaran dengan menggunakan strategi metakognitif diharapkan mampu meningkatkan kemampuan komunikasi matematis siswa. Pembelajaran strategi metakognitif mendorong siswa untuk merefleksikan proses belajar mereka, interaksi dengan orang lain sehingga memberikan peluang bagi siswa untuk berkomunikasi mengemukakan ide atau gagasan matematisnya baik secara lisan maupun tulisan.

Selain pemilihan strategi yang tepat dalam pembelajaran, terdapat faktor lain yang mempengaruhi hasil belajar salah satunya kemandirian belajar (Risnawati, 2013). Menurut Tirtarahardja dan Sulo (2010) kemandirian belajar diartikan sebagai aktivitas yang didorong oleh kemauan sendiri, pilihan sendiri, dan tanggung jawab sendiri dari pembelajar. Siswa yang memiliki kemandirian belajar yang kuat, dia tidak akan mudah menyerah karena dia percaya dengan kemampuan yang dimilikinya. Dengan kepercayaan terhadap kemampuannya sendiri secara sadar, teratur dan disiplin berusaha bersungguh-sungguh, pada akhirnya dapat meningkatkan kepercayaan diri mereka untuk berkomunikasi mengemukakan ide atau gagasan matematisnya.

\section{METODE}

Jenis penelitian ini adalah quasi experimental dengan desain penelitian nonequivalent posttest only control group design. Populasi dalam penelitian ini adalah seluruh siswa kelas VIII SMPN 13 Pekanbaru tahun ajaran 2018/2019. Pengambilan sampel dilakukan dengan menggunakan teknik purposive sampling.

Instrumen dalam penelitian ini adalah tes kemampuan komunikasi matematis, angket kemandirian belajar, serta lembar observasi guru dan siswa. Kualitas dari suatu instrumen penelitian dapat mempengaruhi kualitas hasil penelitian. Oleh karena itu, instrumen penelitian tes kemampuan komunikasi matematis terlebih dahulu diuji validitas, reliabilitas, daya pembeda dan tingkat kesukarannya. Sedangkan angket kemandirian belajar siswa terlebih dahulu di uji validitas dan reliabilitasnya. Pengujian validitas menggunakan korelasi product moment pearson sedangkan pengujian reliabilitas menggunakan rumus alpha.

Untuk kemandirian belajar siswa, angket diberikan di awal pada kelas eksperimen dan kelas kontrol. Skala kemandirian belajar siswa dikelompokkan menjadi tinggi, sedang dan rendah. 
Kriteria pengelompokan kemandirian belajarnya ditentukan sebagai berikut (Muhandaz, Trisnawita \& Risnawati, 2018)

Tabel 1. Kriteria Penilaian Kemandirian Belajar

\begin{tabular}{cc}
\hline Kriteria & Kategori \\
\hline $\boldsymbol{S} \boldsymbol{R} \boldsymbol{L} \geq \overline{\boldsymbol{X}}+\boldsymbol{s}$ & Kelom[ok Tinggi \\
$\overline{\boldsymbol{X}}-\boldsymbol{s}<\boldsymbol{S} \boldsymbol{R} \boldsymbol{L}<\overline{\boldsymbol{X}}+\boldsymbol{s}$ & Kelompok Sedang \\
$\overline{\boldsymbol{X}}-\boldsymbol{s} \leq \boldsymbol{S} \boldsymbol{R} \boldsymbol{L}$ & Kelompok Rendah \\
\hline
\end{tabular}

Teknik analisis data yang digunakan untuk menguji hipotesis 1 adalah uji-t sedangkan untuk hipotesis 2 dan 3 menggunakan Anova Dua Arah. Hipotesis dalam penelitian ini sebagai berikut :

\section{Hipotesis I}

$\mathrm{H}_{o}$ : Tidak terdapat perbedaan kemampuan komunikasi matematis antara siswa yang memperoleh pembelajaran strategi metakognitifdengan siswa yang memperoleh pembelajaran tanpa strategi metakognitif

$\mathrm{H}_{a}$ : Terdapat perbedaan kemampuan komunikasi matematis antara siswa yang memperoleh pembelajaran strategi metakognitifdengan siswa yang memperoleh pembelajaran

\section{Hipotesis II} pembelajaran tanpa strategi metakognitif

$\mathrm{H}_{o}$ : Tidak terdapat perbedaan kemampuan komunikasi matematis antara siswa yang memiliki kemandirian belajar tinggi, sedang dan rendah

$\mathrm{H}_{a}$ : Terdapat perbedaan kemampuan komunikasi matematis antara siswa yang memiliki Hipotesis III kemandirian belajar tinggi, sedang dan rendah

$\mathrm{H}_{o}$ : Tidak terdapat interaksi antara strategi pembelajaran dengan kemandirian belajar dalam mempengaruhi kemampuan komunikasi matematis siswa

$\mathrm{H}_{a}$ : Terdapat interaksi antara strategi pembelajaran dengan kemandirian belajar dalam mempengaruhi kemampuan komunikasi matematis siswa

\section{HASIL}

Sebelum membahas hasil uji hipotesis penelitian, berikut dipaparkan hasil observasi aktivitas guru dan siswa selama penelitian. Gambar berikut menunjukkan persentase keterlaksanaan strategi metakognitif yang dilakukan guru.

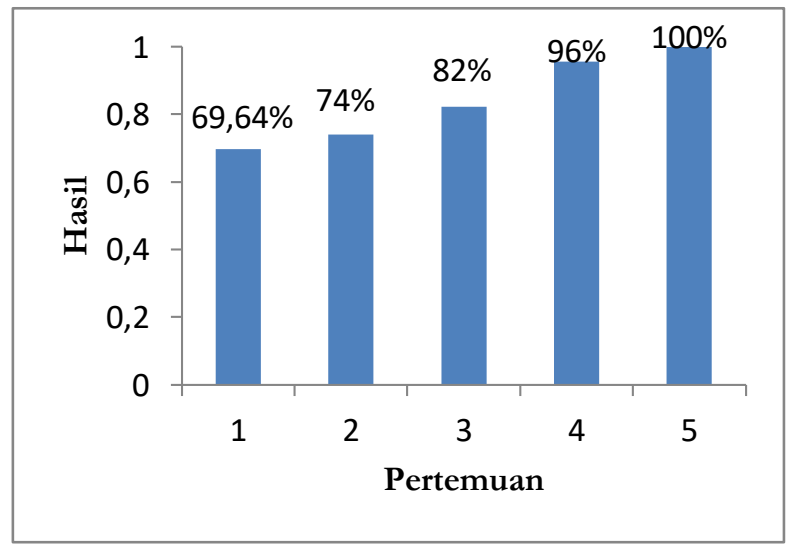

\section{Gambar 1. Grafik Persentase Keterlaksanaan Aktivitas Guru pada Strategi Metakognitif}

Berdasarkan gambar 1 tampak bahwa keterlaksaan aktivitas guru menggunakan strategi Metakognitif dalam setiap pertemuan mengalami peningkatan. Selanjutnya, pada gambar berikut ditunjukkan persentase keterlaksanaan strategi metakognitif oleh siswa di setiap pertemuan. 


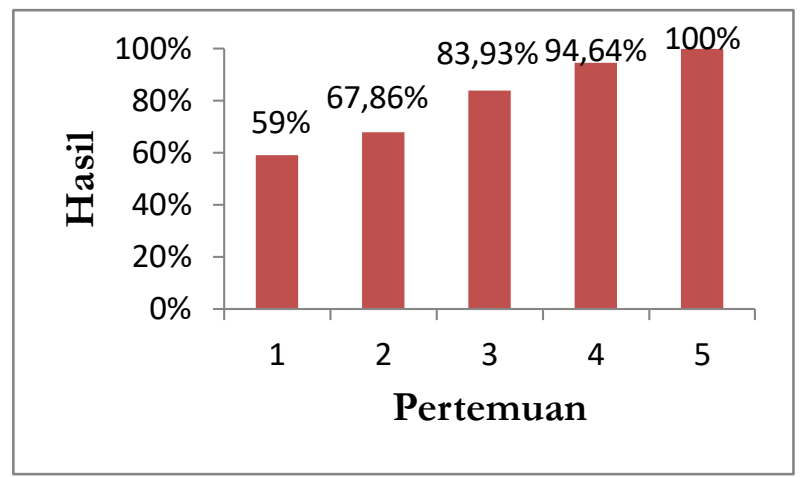

\section{Gambar 2. Grafik Persentase Keterlaksanaan Aktivitas Siswa pada Strategi Metakognitif}

Berdasarkan gambar 2, keterlaksanaan aktivitas siswa dengan menggunakan strategi Metakognitif sangat baik dilihat dari peningkatan setiap pertemuan. Karena pada pertemuan ke-5, baik aktivitas guru maupun siswa sudah terlaksana 100\%, maka pada pertemuan berikutnya dilaksanakan posttest untuk mengukur kemampuan komunikasi matematis siswa. Rata-rata hasil uji kemampuan komunikasi matematis siswa kelas kontrol dan kelas eksperimen dapat di lihat pada gambar berikut :

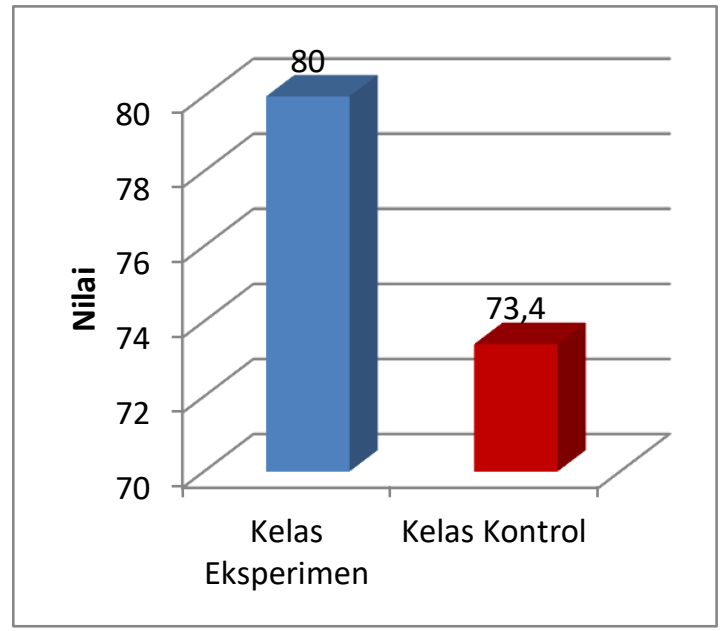

\section{Gambar 3. Perbandingan nilai rata-rata posttest kelas eksperimen dan kontrol}

Dari gambar di atas, terlihat bahwa rata-rata kemampuan komunikasi matematis siswa kelas eksperimen lebih tinggi 6,6 poin dibanding kelas kontrol. Untuk memastikan signifikansi perbedaan tersebut maka akan dilakukan uji statistik rata-rata kedua kelas. Sebelumnya, akan dilakukan uji normalitas dan uji homogenitas untuk menentukan uji statistik yang akan digunakan. Uji normalitas menggunakan rumus chi kuadrat sedangkan uji homogenitas menggunakan rumus Uji F. Berikut hasil uji normalitas dan uji homogenitas posttest.

Tabel 3.Hasil Uji Normalitas Posttest

\begin{tabular}{llll}
\hline \multicolumn{1}{c}{ Kelas } & $\boldsymbol{X}_{\text {hitung }}$ & $\boldsymbol{X}_{\text {tabel }}{ }_{\text {tabel }}$ & Kriteria \\
\hline Eksperimen & 3,39 & 12,59 & Normal \\
Kontrol & 7,92 & 12,59 & Normal \\
\hline
\end{tabular}

Berdasarkan tabel 3, pada kelas eksperimen diperoleh $X^{2}{ }_{\text {hitung }}=3,39$ dan $X^{2}$ tabel $=$ 12,59. Karena $X^{2}$ hitung $<X^{2}$ tabel maka data berdistribusi normal. Begitu juga pada kelas kontrol diperoleh $X^{2}{ }_{\text {hitung }}=7,92$ dan $X^{2}$ tabel $=12,59$. Karena $X_{\text {hitung }}^{2}<X_{\text {tabel }}^{2}$ maka data juga berdistribusi normal. 
Tabel 4.Hasil Uji Homogenitas Posttest

\begin{tabular}{ccccc}
\hline Nilai Varians & Eksperimen & Kontrol & $\boldsymbol{F}_{\text {hitung }}$ & $\boldsymbol{F}_{\text {tabel }}$ \\
\hline $\boldsymbol{S}^{\mathbf{2}}$ & 165,1256 & 216,8502 & \multirow{2}{*}{1,23} & 1,84 \\
$\mathbf{N}$ & 40 & 39 & & \\
\hline
\end{tabular}

Berdasarkan tabel 4 , diperoleh $F_{\text {hitung }}=1,237$ dan $F_{\text {tabel }}=1,84$. Karena $F_{\text {hitung }}<$ $F_{\text {tabel }}$ maka dapat disimpulkan kedua varians homogen.Karena data berdistribusi normal dan homogen, maka untuk pengujian hipotesis 1 menggunakan uji-t. Hasil perhitungan terhadap uji-t posttest kemampuan komunikasi matematis dapat dilihat pada tabel 5 .

\section{Tabel 5.Hasil Uji-t Posttest}

\begin{tabular}{cc}
\hline $\boldsymbol{t}_{\text {hitung }}$ & $\boldsymbol{t}_{\text {tabel }}$ \\
\hline 2,16988 & 1,99045 \\
\hline
\end{tabular}

Untuk hipotesis pertama, berdasarkan hasil uji-t pada tabel 3 diperoleh $t_{\text {hitung }}>t_{\text {tabel }}$ dengan $t_{\text {hitung }}=2,16988$ dan $t_{\text {tabel }}=1,99045$, sehingga $H_{o}$ ditolak. Artinya, terdapat perbedaan yang signifikan kemampuan komunikasi matematis antara siswa yang mengikuti pembelajaran strategi metakognitif dengan siswa yang mengikuti pembelajaran konvensional.

Selanjutnya, akan dipaparkan hasil uji hipotesis 2 dan 3. Karena melibatkan lebih dari dua variabel, maka uji hipotesis dilakukan dengan anova dua arah. Hasil perhitungan terhadap uji anova dua arah dapat dilihat pada tabel 6.

Tabel 6. Hasil Uji Anova Dua Arah

\begin{tabular}{cccccc}
\hline Varians & Dk & JK & RK & Fh & Fk \\
\hline A & 1 & 77,75 & 860,51 & 11,07 & 3,97 \\
B & 2 & 9492,66 & 4746,33 & 61,05 & 3,12 \\
(A X B) & 2 & $-90,35$ & $-45,17$ & $-0,58$ & 3,12 \\
\hline
\end{tabular}

Untuk hipotesis yang kedua, berdasarkan tabel 3 terlihat bahwa $F(B)_{\text {hitung }}<$ $F(B)_{\text {tabel }}$ atau 61,05> 3,12 sehingga $H_{o}$ ditolak. Artinya, terdapat perbedaan kemampuan komunikasi matematis antara siswa yang memiliki kemandirian belajar tinggi, sedang dan rendah. Terakhir, untuk hipotesis yang ketiga pada tabel 6 terlihat bahwa $F(A \times B)_{\text {tabel }}<F(A \times$ $B)_{\text {tabel }}$ atau $-0,58<3,12$ sehingga sehingga $H_{o}$ diterima. Artinya, tidak terdapat interaksiantara strategi metakognitif dengan kemandirian belajar terhadap kemampuan komunikasi matematis siswa.

\section{PEMBAHASAN}

Sebagaimana telah dipaparkan bahwa penelitian ini bertujuan untuk melihat apakah terdapat perbedaan kemampuan komunikasi matematis siswa yang menggunakan strategi metakognitif dengan siswa yang memperoleh pembelajaran konvensional ditinjau dari kemandirian belajar siswa. Hasil analisis data menunjukkan bahwa terdapat perbedaan yang signifikan kemampuan komunikasi matematis antara siswa yang belajar dengan strategi metakognitif dengan siswa yang belajar memperoleh pembelajaran konvensional. Hal ini terjadi karena siswa yang belajar dengan strategi metakognitif diarahkan kepada kesadaran proses berpikir bagaimana merancang, memonitor, serta mengontrol tentang apa yang mereka ketahui, apa yang diperlukan untuk mengerjakan dan bagaimana melakukannya (Suzana, 2004). Ketiga tahapan tersebut, dituangkan dalam bentuk pertanyaan-pertanyaan metakognitif. Melalui pertanyaan tersebut, kemampuan komunikasi siswa dilatih. Hal ini juga dipertegas oleh Howard (2004) bahwa metakognitif memegang peranan penting pada banyak tipe aktivitas kognitif termasuk pemahaman, komunikasi, perhatian (attention), ingatan (memory), dan pemecahan masalah. 
Dalam pembelajaran dengan strategi metakognitif, guru memancing pertanyaan, dan menanggapi jawaban yang diajukan siswa sehingga dapat membangkitkan aktivitas berpikir dan berbicara tentang matematika serta mendorong siswa untuk terlibat dalam komunikasi. Interaksi tersebut memberikan kesempatan kepada siswa untuk mengkomunikasikan ide-ide matematisnya baik secara tertulis maupun lisan.

Hasil penelitian yang diperoleh pada penelitian ini juga sejalan dan mendukung penelitian yang dilakukan oleh Susantri (2017). Ia menyimpulkan bahwa peningkatan kemampuan komunikasi matematis siswa yang menggunakan strategi metakognitif lebih baik dibanding kemampuan komunikasi matematis siswa yang memperoleh pembelajaran konvensional. Menurut Susantri (2017), hal ini dapat terjadi karena siswa berdiskusi dengan teman sekelompoknya, bertukar pikiran, berbagi ide, memonitor kesadaran berpikir mereka dan bila perlu mengajukan pertanyaan kepada guru.

Hasil uji anova dua arah menunjukkan bahwa terdapat perbedaan signifikan antara siswa yang menggunakan strategi metakognitif dengan siswa yang memperoleh pembelajaran konvensional ditinjau dari kemandirian belajar siswa. Hasil ini serupa dengan penelitian yang dilakukan oleh Afiani (2016). Ia menyimpulkan bahwa terdapat pengaruh yang signifikan kemampuan komunikasi matematis dan kemandirian belajar secara bersama-sama terhadap prestasi belajar matematika. Hal ini karena anak yang memiliki ciri kemandirian belajar berupa memiliki rasa percaya diri, bertanggung jawab dan mampu mengambil keputusan akan berpengaruh positif terhadap prestasi belajarnya (Yanti \& Surya, 2015).

Terakhir, hasil analisis menggunakan uji anova dua arah menunjukkan tidak terdapat interaksi antara strategi pembelajaran dengan kemandirian belajar dalam mempengaruhi kemampuan komunikasi matematis siswa. Dengan kata lain strategi pembelajaran terhadap kemampuan komunikasi matematis tidak bergantung pada kemandirian belajar, dan kemandirian belajar terhadap kemampuan komunikasi matematis tidak bergantung pada strategi pembelajaran yang digunakan.

\section{KESIMPULAN}

Berdasarkan hasil penelitian dan analisis data yang telah dilakukan, dapat disimpulkan bahwa:

1. Terdapat perbedaan kemampuan komunikasi antara siswa yang mengikuti pembelajaran strategi metakognitif dengan siswa yang mengikuti pembelajaran konvensional.

2. Terdapat perbedaan kemampuan komunikasi matematis antara siswa yang memiliki kemandirian belajar tinggi, sedang dan rendah.

3. Tidak terdapat interaksi antara strategi metakognitif dan kemandirian belajar siswa dalam mempengaruhi kemampuan komunikasi matematis siswa.

\section{DAFTAR PUSTAKA}

Afiani, N. (2016). Pengaruh Kemampuan Komunikasi Matematis dan Kemandirian Belajar terhadap Prestasi Belajar Matematika. Journal JKPM ,2(1), 1-13

Ansari, B.I. (2015). Komunikasi Matematik, Strategi Berpikir dan Manajemen Belajar. Banda Aceh: Pena

Hendriana, H, Rohaeti,E.E. \& Sumarmo,U. (2017). Hard Skills dan Soft Skills Matematike Siswa. Bandung : RefikaAditama.

Howard, J. B. (2004). Metacognitive Inquiry. School of Education Elon University, 1-3

Menteri Pendidikan dan Kebudayaan Republik Indonesia. (2016). Peraturan Menteri Pendidikan dan Kebudayaan Republik Indonesia Nomor 21 Tahun 2016 tentang Standar Isi Pendidikan Dasar dan Menengah.Jakarta : Menteri Pendidikan dan Kebudayaan Republik Indonesia. 
Muhandaz, R., Trisnawita, O \& Risnawati.(2018). Pengaruh Model Pembelajaran Course Review Horay terhadap Kemampuan Pemahaman Konsep Matematis Berdasarkan Kemandirian Belajar Siswa SMK Pekanbaru. Juring : Journal for Research in Mathematics Learning 1(2), 137-146.

Noviarni.(2014). Perencanaan Pembelajaran Matematika dan Aplikasinya Menuju Guru Matematika yang Kreatif dan Inovatif. Pekanbaru: Benteng Media

Risnawati.(2013). Keterampilan Belajar Matematika. Pekanbaru : Aswaja

Susantri.R. (2017). Peningkatan Kemampuan Pemahaman Dan Komunikasi Matematis Siswa Sekolah Menengah Pertama Melalui Strategi Metakognitif. Tesis Universitas Pendidikan Indonesia. [Online], tersedia :http://repository.upi.edu/30070/

Syah, M. (2010). Psikologi Belajar. Bandung : PT Remaja Rosdakarya.

Tirtarahardja, U dan Sulo, L. (2010).Pengantar Pendidikan. Jakarta : PT Rineka Cipta.

Tupa, C. (2015). The Influences of Metacognitive Learning Model to the Problem Solving and Communication of Mathematics in Second Class at SMPN 29 Makassar. e-prints Universitas Negeri Malang.

Yamin, M. (2003).Strategi dan Metode dalam Model Pembeajaran. Jakarta: GP Press Group

Yanti, S., \& Surya, E. (2017). Kemandirian Belajar dalam Memaksimalkan Kualitas Pembelajaran. Tesis Universitas Negeri Medan. [Online]. Tersedia : https://www.researchgate.net

Zakaria, E., Nordin, N.M \& Ahmad, S. (2007). Trend Pengajaran dan Pembelajaran. Kuala Lumpur: Prin AD SDN BHD. 